\title{
Impact of Design Changes on Contractors' Cash Flow
}

\author{
M.N. Zainudeen, G.R.S.P. Kumari and T.K.K.S. Seneviratne
}

\begin{abstract}
Several factors affect the cash flow profile of contractors. Among these design changes play a vital role. This research explores the impact of design changes on contractors' cash flow. Twenty completed building projects were selected for the analysis. It was found that design changes have a significant contribution amounting to $50 \%$ of the total cost overruns. Most of the cost overruns took place during $75 \%$ to $100 \%$ stages of the projects. Further, the results show that the impact of design changes to the contractors' cash flow was significant for M3 grade contractors than M1 and M2. When design changes occur, contractors have to search for additional interim finance than planned, often at a higher cost, which reduces their profit margin. Therefore, contractors need to consider the requirement for additional finance that may become a necessity during the execution of a project and incorporate necessary provisions when preparing a cash flow forecast.
\end{abstract}

\section{Introduction}

The globalization of market place and the rapid growth in information flow capabilities have made the construction industry extremely competitive. In such a context, efficient use of financial resources and accurate cash flow forecasting is vital for any contractor in the construction industry for successful operation and survival in the long run. A suitable cash flow model would provide contractors with critical information such as the amount of capital required to perform a contract and the amount of interest payable on overdraft (Lam et al, 2001). Construction contracting largely involves unpredictable and complex processes and outcomes making it a highly risky business. Design changes are inevitable in construction. Hence, construction projects ranging from small to large have failed to keep within the estimated cost, generating cost overruns. It creates significant financial risk to both client and the contractor. To the contractor, it implies loss of profit through penalties for non-completion that could jeopardize his chances of winning future jobs (Mbachu and Nkado, 2004). The cash flow of the contractor can be severely affected due to design changes of a project. Therefore it is imperative to study the impact of design changes on contractors' cash flow as there is a need to bridge the time between making expenditures and obtaining revenues. On this context, this study attempts to identify the impact of design changes on contractors' cash flows.

\section{Methodology}

Unstructured interviews were conducted with contractors and selected professionals in the industry to gather relevant information. Case studies in the form of document surveys were carried out to collect necessary data. Twenty completed building projects were used as the sample size. Twelve contracting organization were selected for the provision of data. These projects were carried out based on the Institute for Construction Training and Development (ICTAD) form of contract, during the period of 2000 to mid of 2006 in Sri Lanka, executed by private sector contracting organizations which have the ICTAD grading of M1 - M3. Selected projects were limited to Measure and Pay contracts.

\section{Contractors Cash Flow}

\section{Importance}

A cash flow forecast is the distribution of income and expenditure as a function of time (Navon 1995). According to Kaka and Price (1993), a cash flow forecast and control are essential for survival of any contractor. It should be practiced at different stages of the project life, starting at the bidding stage, where decision to bid for a project can be influenced by financial considerations, such as capital cost and maximum expenditure constraints (Navon, 1995). Cash flow forecasting of individual projects require a clear understanding of contract conditions, work programme and risks (Kaka and Lewis, 2003). A cash flow forecast will help the contractor to plan cash requirements and thereby improve control over his business cash flows and to conserve its cash resources.

Cash is important for day-to- day existence and some contractors have suffered a downturn not because their work was not profitable but due to an insufficiency of cash in the short term (Ashworth, 2004). The construction industry suffers the largest number of bankruptcies of any sector of the economy, with many companies failing because of the poor financial management, especially inadequate attention to the 
cash flow management (Kaka, 1996). Cash is the most important resource of the construction company as more construction companies fail due to lack of liquidity for supporting their day today activities than due to inadequate management of resources (Navon, 1996). Arranging for financing is the first and paramount necessity faced by any contractor. From the very start as a small individual operator or a partner, through all the stages of growth to the largest national or world wide diversified construction organization, the problem of assuring adequate funds to operate contract commitments, provide for overhead, pay wages and salaries, buy and maintain adequate equipment, purchase materials, stand behind losses if they occur remains always present (Bonny and Frein, 1983). The financial risks come from several sources, encompassing the need for intensive capital, typically occurring in many projects, possible delays on client payments and the exposure to the interest rate changes during the period between the contract closing and end of the payment plan (Barbosa and Pimentel, 2001). When there is an increase in the actual cash requirement than predicted, liquidity problem arises. A project cannot be preceded without adequate financing and the cost of providing adequate finance can be quite large creating problems to the contractor. In such a situation, contractors have to bridge the time between making expenditure and obtaining revenue with the limited amount of financial sources. This necessitates the contractors to beg financial institutions for bridging loans. In addition, contractors have to pay a higher rate of interest for the borrowed funds, reducing their profit margin. Therefore higher interest rates have accentuated the industry's problem especially in developing counties like Sri Lanka. Finding funds to execute the work obtained on a contract with design changes is a big burden for the contractors. Therefore it is important to investigate the impact of design changes on the cash flow from a contractor's point of view.

\section{Modes of Financing the Cash Flow}

Short term funds are necessary for businesses to run their day-to-day operations as stated earlier. In the short term, a wide variety of financing options exist including overdraft facilities, loan facilities, trade credit, Construction Guarantee Fund and private sources. Among these, the common source of finance for unexpected cash flow deficits is found to be by bank overdrafts. An overdraft account is a convenient and flexible way of covering contractor's day to day spending and improving his cash flow. Normally, there is a maximum overdraft limit which can be imposed on an overdraft account. In effect overdraft financing depend upon the pattern of cash flow over time. Key features and benefits of overdraft facilities are; contractors have necessary cash flow to run their business, can deal with unforeseen circumstances successfully. The interest rate charge will be subjected to negotiations and it will vary from bank to bank, nature and statues of the borrower etc.
Most of the financing options available to the contractor involve the participation of third parties such as banks or other financial institutions and it is a well known fact that these institutions are generally reluctant to provide credit facilities to construction contractors. Due to inefficient performances and high level of bankruptcies, financial institutes charge higher interest rates from contractors which have become a major constraint for small and medium scale contractors. Hence, financial problems are found common in construction industry. The literature review identified some of the key reasons for financial difficulties faced by contractors that can be summarized as; long delay in receiving payments, unplanned cash flow deficits, difficulties in obtaining bank finance, higher interest charges, non availability of special funds for financing of contractors, difficulties in obtaining securities, guarantees and credit from supplies, higher charges for hiring and leasing plant and equipment, inadequate or lack of provision for price fluctuations, rigid conditions imposed on the contractors, poor financial management skills of contractors and lack of experience in planning and programming (Chan et al, 2005; Arbiti, 2000; Wijesooriya, 1997; Abayadeera, 1996; Abeygunasekara, 1993).

\section{Cash Flow Planning}

Analyzing the cash flow is critical to the success of any business, while companies in the construction industry especially hampered by a lack of cash planning due to the intricate nature of their business (Tremel, 2005). If the cash flows are not planned at early stages (pre contract) of the project and are spread over a number of periods, the problem of uncertainty and ambiguity become serious (Teicholz 1994 cited Boussabaine and Elhag, 1999).

An analysis of working capital and current cash needs does not provide an indication of the contractor's future cash flow needs. It neither show a company's ability to handle a cash flow interruption due to a problem on a current contract and nor indicate future cash need if a new project is awarded (Tremel, 2005). Therefore it implies that to gain this information, it is essential to prepare a cash flow forecast.

Similar to other management tools, cash flow forecasting is a repeated process. At first, a forecast, plan or target is complied and then when the project is in progress, the performance is measured and compared with the plan (Navon, 1995). If there is inconsistency between planed and actual performance, the plan has to be adjusted to meet the original target or at least to attain it as closely as possible. The aspect of short term financing is decisive in the construction industry than other industries and on such a scenario, cash flow forecast provides a framework for contractors in their operations.

Accurate cash flow forecasting at the tender stage provides contractors with information regarding the 
amount of capital required to perform a contract, the amount of interest that needs to be paid to support the overdraft and the evaluation of different tendering strategies (Kaka, 1996). According to Peer (1982), a reliable cash flow plan, as "insurance" against the risk of overtrading, is an indispensable tool for any firm.

Cash flow forecasting is, like any forecasting, the result of calculations based on the information available at the time and a few assumptions to what will happen (Harris and McCaffer, 2001). In most current practices, the accuracy of cash flow forecasting is largely dependant on the past experience of the estimator performing the forecast (Boussabaine et.al, 1999). For cash flow analysis there are many different methods and techniques available. Most of these methods are based on a single standard S curve (Kaka, 1993). Cash flow forecast of a project can be derived from two methods;

\section{1) Using basic input data}

In practice the project cash flow can be derived from the master programme in conjunction with the financial appraisal of the contractor. The factors to be considered in preparing the cash flows are; the form of contract, the contractor's own trade conditions and the conditions of banks/lending institutions. It is also important to consider other factors like bonds, including dates of release, the recovery of price fluctuations, any special weighting that may be incurred on the contract, provision for liquidated damages and the amount of prime cost and provisional sums.

\section{2) Using historic cash flow}

This is another method for preparation of a cash flow forecast. By analyzing the historical database of cash flows, most appropriate cash flow forecast can be selected for the particular project and prediction of the cash flow for the new project can be carried out by using this selected cash flow.

Having examined some key considerations in terms of the cash flow, the next part of this paper examines the impact of cost overruns on cash flows.

\section{Impact of Design Changes on Contractors' Cash Flow}

\section{Causes of Construction Cost Overruns}

The problem of cost overruns, especially in the construction industry is a worldwide phenomenon and its ripples are normally a source of friction between client and the contractor on the issue of project cost variation (Creedy, 2005). Poor cost performance of construction projects has been a major concern for both contractor and client (Baloi and Price, 2004). To the industry as a whole, cost overruns could bring about project abandonment and a drop in the building activities, bad reputation and inability to secure project finance or securing it at higher costs due to added risks (Mbachu and Nkado, 2004).
The reasons for construction cost overruns are almost similar to every project with varying degrees. Some of them are related to each other and all are associated with some form of risk. The common causes for cost overruns in building projects have been identified as; design changes, increase or decrease of the value of $\mathrm{BOQ}$ items, price and currency fluctuations, day works and claims (Rexi, 2004). Among these, design changes is the primary cause for cost overruns. In the present context, design changes is the main cause for cost overruns in Sri Lankan construction industry (Suganthan, 2005; Rexi 2004).Design changes are never ending and hectic in the construction industry which directly affects the cost and time overruns. On large construction projects the number of design changes may run into thousands, often valued at millions of rupees (Mushthak, 2005). Design changes are the most significant contributory factor resulting in variations. According to Jackson (2004), design changes to the project are the primary cause for cost overruns. With change there is sometimes a vicious circle where innovations attempt to improve the value for money of facilities but this is then followed by increased complexity and an increased degree of uncertainty generating cost overruns.

Design changes occur due to alteration in the design of architectural, structural, services and other portion of the building either carried out by the main contractor or by the nominated sub contractors. Especially design changes occur either due to errors and /or omissions in the drawings and specifications and the other contract documentation, and in those areas of the building design not covered both by the main contractor / nominated sub contractors (Rexi, 2004). Another reason for design changes is the consultant's instructions on site when the intended design is not satisfactory for them. In some instances, the consultants are forced to use the drawings and details of similar work for the proposed project due to time constraints for preparing drawings, specification etc. These designs have to be changed when executing the work, as it may not be compatible with the intended purposes leading to cost overruns.

\section{Cost Overruns vs. Contractors' Cash Flow}

Poor cost performance of construction projects thus seems to be the norm rather than the exception particularly in developing countries where the problem is more acute (Baloi and Price, 2004).

According to Wijekoon (2005), cost overruns are one of the most critical factors that affect the cash flow profile of contractors. Due to cost overruns, negative cash flows can stem leading to out comes ranging from trivial to vary serious. As a result the actual rate of expenditure exceeds the predicted rate of expenditure, raising the need of working capital (Lowe and Whitworth, 1996). In the case of complex projects the problem of uncertainty and ambiguity assume even greater proportions because of the difficulty in predicting the impact of unexpected 
changes on construction progress and consequently on cash flows (Boussabaine and Elhag, 1999). In simple projects cost overruns might mean no more than the overhead costs associated with obtaining additional working capital or interest payments on extra short term borrowing. However, it could mean lost profits on contracts which encounter inadequate working capital or even insolvency in extreme cases.

As design changes are found to be the principal cause of cost overruns, it is imperative to study the influence of design changes on the cash flows of contractors. Sluggish economic growth and highly competitive market conditions force contractors to reduce their markups to remain competitive. In such a situation, even a marginal cost overburden can sweep away the profit of a job and continuous cost overburdens in most of the projects of a firm can lead to bankruptcy (Akincl and Fischer, 1998).

Design changes are inevitable in even the best planned contracts due to the high probability of unforeseen risks and the advancement of technology rendering high complexity. Conversely, design changes often occur quite unnecessarily, simply as the client had not been capable of making his mind precisely at the design stage about what he wants or due to lack of foresight on the part of the design team.

In any case design changes may not be identified at the project planning stage. Normally cash flow forecast is based on the pre construction programme and the priced $\mathrm{BOQ}$ where the effects of design changes are not considered. When the scope of work is assorted, many tasks may be affected both directly and indirectly forming a momentous impact to the contractor's cash flow profile. Unexpectedly contractor may require an additional amount of interim finance than forecasted, generating financial burden to the contractor where he has to incur additional financing cost and loss of earning. In addition the contractor has to change the resource requirements, rework and may have to face the consequence of time lost in stopping and restarting current tasks in order to make the variation. This can lead to loss of rhythm, unbalanced gang plus acceleration, all of which could result in negative impact on cash flow (Bower, 2000).

\section{Findings}

The selected sample of twenty projects comprises of residential, commercial and other buildings. Residential buildings are that used for residential purpose. Commercial buildings consisted of office buildings, shopping complexes and banks and the "other buildings" compromised of educational buildings and hospitals. Summary of the cost overruns of the projects are given in Table 1. (Refer Appendix).

\section{Analysis of Cost Overruns in Different Stages of Projects}

Data required for the analysis were cumulative value of work done for each month of the project excluding cost overruns and cumulative cost overruns for each month of the project. Every project is converted in to $100 \%$ time and $100 \%$ value from available data instead of generating standard S curves even though the projects did not have similar intervals. This method is adopted as it suffices the comparison purpose.

The base figure of $100 \%$ was taken as the practical completion on site. The origin was taken as the commencement of work. By plotting \% of time against $\%$ of value as bar charts for every project, the pattern of cost overruns was observed.

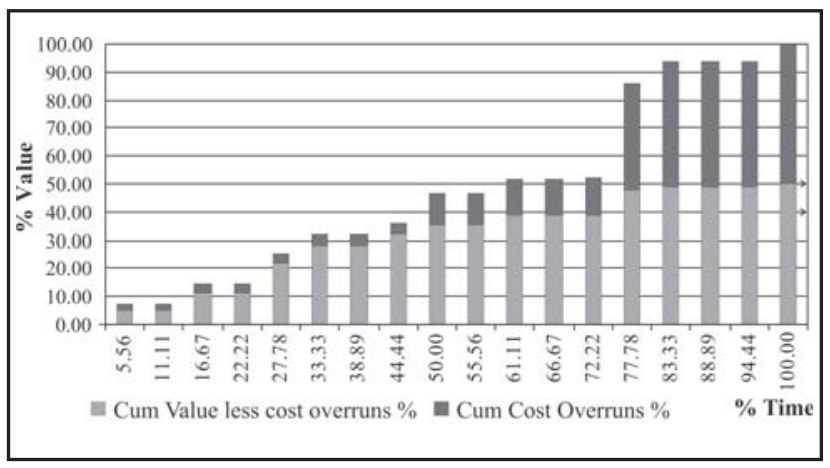

Figure 1: Cumulative Value \& Cumulative Cost Overruns for Different Stages of Projects

It was found that, only eight projects out of twenty had cost overruns in the first month and it was $40 \%$ from the total projects. Therefore, occurrence of the cost overruns in the very beginning of the contract was lesser for the concerned projects.

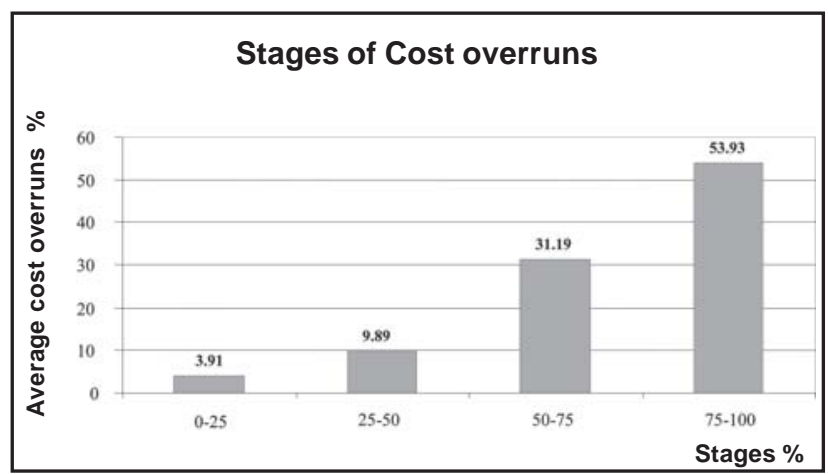

Figure 2: Summary of Cost Overruns in Different Stages

Figure 2 above shows the summary of results from the analysis. From the beginning till $25 \%$ of completion of the projects only $3.91 \%$ cost overruns have occurred. $14.88 \%$ cost overruns have occurred till $50 \%$ completion of the projects which is comparably a small figure. During the $50 \%$ to $75 \%$ stages $31.19 \%$ cost overruns occurred. Results show that $53.93 \%$ of cost overruns have occurred during $75 \%$ to $100 \%$ stages of the projects. It is clear that the contractors' risk of cost overruns is higher at the latter stages of the projects than initial stages. This is an important issue for the contractor when planning his cash flows and arranging the interim finance. 


\section{Composition of Cost Overruns}

According to the data collected, it was found that variations have a significant contribution amounting to $50 \%$ for the total cost overruns (refer figure 3 ). And also the impact of price fluctuation ( $40 \%$ ) to the cost overrun cannot be disregarded. BOQ item increase or decrease which is $8 \%$ of the average cost overrun is comparatively low when compared to variations and price fluctuations.

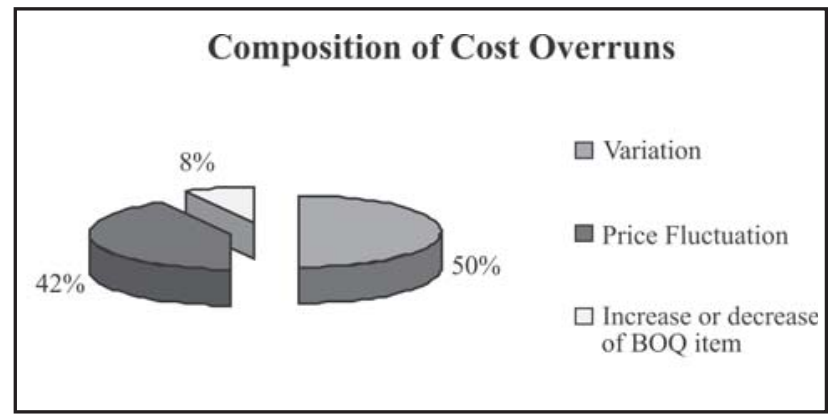

Figure 3: Compositions of Cost Overruns

\section{Analysis of Impact of Design Changes on Contractors' Cash Flow}

Calculating the opportunity cost to the contractor was selected as the method of measuring the impact of design changes on contractors' cash flow. In other words, the amount of design changes for a particular time period and additional interest charges that the contractor had to bear for unexpected interim finance were taken in to account when determining the opportunity cost for the contractor.Price fluctuations were not considered for this, as it is generally considered by the contractor during pricing of Bill of Quantities. As mentioned earlier, 20 projects carried out by M1, M2 and $\mathrm{M} 3$ contractors were selected as case studies.

The data required for the analysis were value of work done, actual cost, income, value of design changes and relevant interest rates for additional overdraft financing. These data were collected for every month of the projects. All direct costs and site overheads were considered as the actual cost. By plotting value, cost and income against time, the project cash requirements can be derived. Monthly net cash flows were derived from deducting monthly expenditure from monthly income. From the interviews, it was found that all selected contractors use overdraft as a short term financing source in addition to trade credit. When calculating the opportunity cost, relevant overdraft interest rates for particular organizations in relevant years were used and in the absence of such data average interest rates were applied considering the similar grading.

For computation of the opportunity cost, it was assumed that when there were cost overruns the contractor had to exceed his normal overdraft limit and had to pay additional interest rates for bridging finance. Opportunity cost per month was calculated using the following equation.
Opportunity Cost per month = Design changes for $\mathrm{X}$ Relevant overdraft interest rate for

Opportunity cost of the contractor for a particular month was derived by applying appropriate interest rate for the value of design changes in that month. Then overall opportunity cost of the project was calculated by adding each month's opportunity costs if such month had design changes. The derived opportunity cost is presented as a percentage of profit for each project as shown in Figure 4 below.

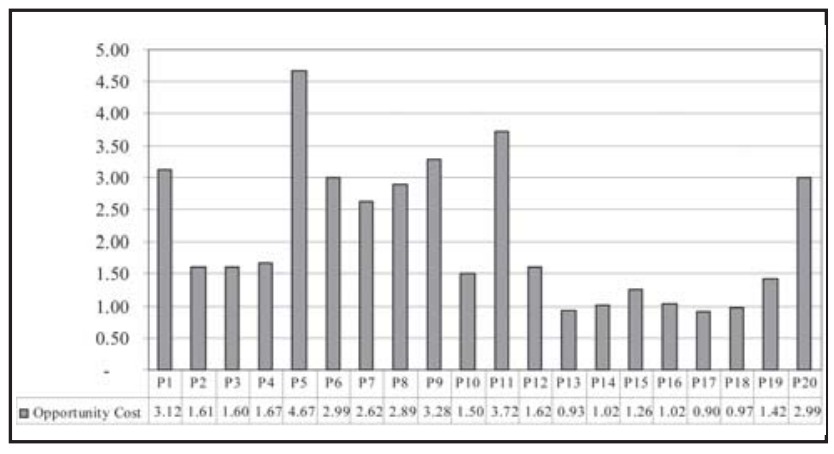

Figure 4: Percentages of Opportunity Cost

In order to have a clear idea regarding the impact according to the contractor's grading, mean and standard deviation were compared, the results of which are given in table 2. The lowest mean of 1.79 was for the M1 contractors. M3 category had the highest mean of 2.53. Results demonstrated that, the effect of design changes on contractor's cash flow varied according to the ICTAD grading of the contractors. M3 contractors had highest impact compared to M1 and M2 contractors. M2 contractors had more impact than M1 but lesser than $\mathrm{M} 3$.

Table 2: Effect of Design Changes of Different Grade of Contractors

\begin{tabular}{|c|l|c|}
\hline ICTAD Grading & Mean & SD \\
\hline M1 & 1.79 & 0.91 \\
M2 & 1.81 & 1.31 \\
M3 & 2.53 & 1.16 \\
\hline
\end{tabular}

Above findings show that the design changes occurred in these projects generated opportunity cost for the contractors affecting their cash flows. Therefore, due to design changes, financing cost increases than expected to the contractor forcing him to seek bridging finance till the client reimburses the payment. Consequently it was the additional cost for the contractor which ultimately led to reduction in profit margin. 


\section{Practitioners' View on Impact of Design Changes to the Contractors' Cash Flow}

According to the interviewed practitioners' view, there may be an impact to the cash flow of the contractors due to unexpected design changes. When there is an unexpected shortage in their cash flow they have to exceed the normal overdraft limit resulting in additional interest payment which will ultimately reduce their profit margin. When design changes arise for all projects this becomes critical for the contractor's cash flow as M1 contractors handle ten to twelve projects on average per year and $\mathrm{M} 2$ and $\mathrm{M} 3$ contractors handle thirteen to fifteen projects on average per year. However, in accordance with the professionals' view, this impact may vary from contractor to contractor according to their financing capabilities and management skills, time period, projects in hand, condition of contract applicable to the project and economic conditions etc.

According to the interviews conducted with M1 contractors, it was found that when there is a design change and cost overrun, they apply several strategies; delay payments to the suppliers and sub contractors, overdraft finance, cash pumping from other projects and use of mobilization payment of new projects to cover this unexpected deficit in the cash flow. When the impact is significant and the overall working capital requirement of the organization is elevated they have to resort to over drafts at higher rates.

Based on the M2 and M3 contractors' view, it was found that the impact on their cash flow due to design changes may be higher compared to M1 contractors. The reasons for this are poor financial management abilities, inexperience in cash flow forecasting project wise plus company wise, lack of credit facilities from financial institutions and lower overdraft limits than M1 contractors. Therefore, management of overall project and company cash flows to have a positive working capital is important for them.

\section{A Model Case Study}

In order to demonstrate the impact of cost overruns on contractors cash flow, a model case study has been selected and analysed below, the detail of which is given in table 3.

Table 3: Project Details

\begin{tabular}{|l|c|}
\hline Type of Building & Bank \\
\hline Final Account Sum (Rs.) & $25,011,456.32$ \\
\hline Cost overruns & $4,946,665.32$ \\
\hline$\%$ of Cost Overruns & $24.65 \%$ \\
\hline $\begin{array}{l}\text { Source of Short-term Finance of } \\
\text { the Contractor }\end{array}$ & Overdraft with limit of Rs. 15 million \\
\hline Duration & 13 Months \\
\hline Time Overruns & I Month \\
\hline Defect Liability Period & I2 Months \\
\hline Grading of the Contractor & M3 \\
\hline Procurement System & Separated/ Measure and Pay \\
\hline Advance Payment & 20\% of the initial contract sum \\
\hline Payment Lag & I Month \\
\hline
\end{tabular}

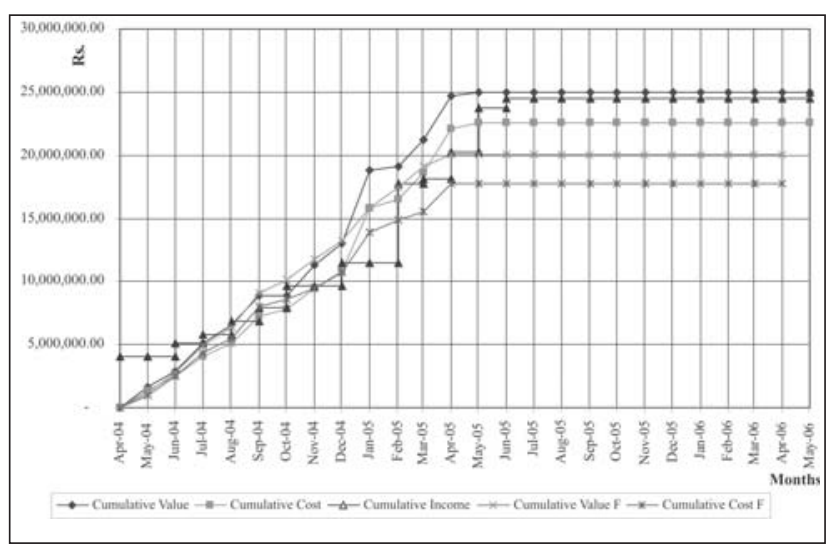

Figure 5: Actual and Forecasted Cash flows of the Project

When analysing the impact of design changes to the contractor's cash flow, it is vital to consider the actual vs. planned cash flows of a project. Despite the assumption that the value curve of the contractor is " $S$ " shaped, most of the time in real practice it is not standardized due to cost overruns, time overruns, payment delays by the client etc., and this is the case with this project too(refer figure 5). When looking at the cash flows of the project, it can be perceived that from the beginning of April to August 2004 actual value curve of the project was slightly above the forecasted cash flow. However, due to the impact of mobilisation advance payment the contractor was having a positive cash flow even though there was deviation from actual vs. planned cash flows.

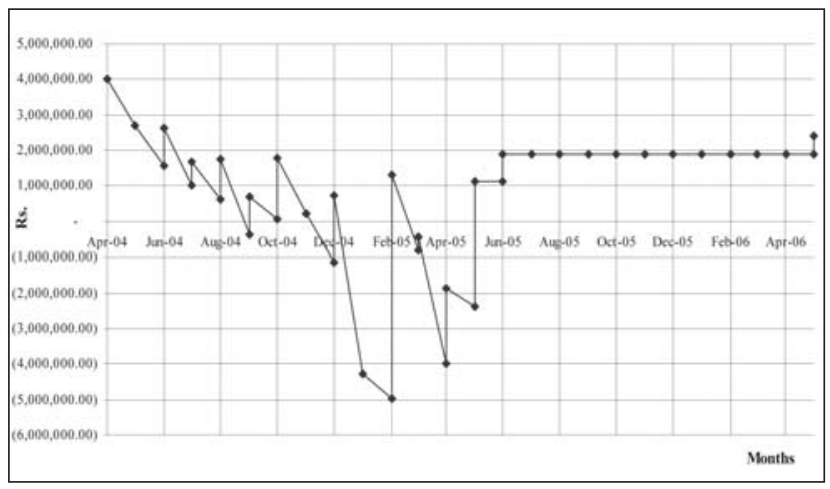

Figure 6: Cumulative Net Cash Flow of the Project

From August to December 2004, forecasted value curve was slightly above the actual value curve and from December 2004 to completion, actual cash flow was above the forecasted cash flow. According to the cash flow analysis, the contractor had to face a maximum overdraft requirement of Rs. 4.96 million as indicated in the figure 6 . Considerable deviation in the forecasted vs. actual value curve can be noticed during January 2005 as Rs. 1.45 million of cost overruns occurred due to changes in the floor finishes and aluminium doors and windows. As a result of this cost overrun, contractor had to use interim finance till his cost was reimbursed by the client. According to the information obtained from the contractor, he had to exceed his normal overdraft limit of Rs. 15 million due to this cost overrun as there 
was no sufficient working capital in his organisation. As result, he had to incur $26.5 \%$ interest rate per annum instead of $13 \%$ normal interest charges affecting his profit margin.

\section{Conclusion}

Proper planning and prediction of cash flows ensure healthy and steady growth to the contractors. This study is an initial step taken to identify the impact of design changes on the cash flow from contractor's perspective. Cost deviation from estimated to actual is a common problem in Sri Lankan construction industry creating financial risk to both contractor and client. Results of the study illustrate that design changes has the highest contribution for cost overruns amounting to $50 \%$ of average cost overruns.

Identification of the stages of the projects where most cost overruns occur is imperative for the contractors in terms of financial management, cost control and risk management. According to the research findings, $53.93 \%$ of the cost overruns took place during $75 \%$ to $100 \%$ stages of the projects, which is significant. From the beginning to $50 \%$ completion of the projects, only $14.88 \%$ cost overruns occurred which is a comparatively small figure. Therefore, the contractors should take necessary steps during the $75 \%$ to $100 \%$ completion stage to minimize cost overruns as there is more probability than other stages.

When there are design changes, liquidity problem arises without prior warning affecting the cash flow of contractors. Design changes may take the form of opportunity costs involved with increasing working capital requirement or additional external borrowing. Results of the study demonstrated that design changes occurred during the execution of the projects had an impact on the contractors' cash flow and this impact is varied from project to project even for the same contractor.

According to the analysis, impact of design changes to the contractors' cash flow was significant for M3 contractors than $\mathrm{M} 1$ and $\mathrm{M} 2$ contractors. Design changes have a higher impact on M3 contractors as their markup is generally lower than $\mathrm{M} 1$ and $\mathrm{M} 2$ contractors. However, with the increasing competition in the industry, contractors tend to go for lower mark up to win the project. On such a case, actual unit bid price will probably be higher than estimated due to potential opportunity cost of capital.

The findings of this study has revealed some important considerations that the contractor need to make in preparing cash flows in order to make provisions for unexpected working capital requirements and to avoid borrowings at a higher interest rate than usual.

\section{References}

ABEYDEERA, S. T., 1996, Causes for Failures in Sall Scale Contracts for School Buildings. Unpublished Dissertation (B.Sc). University of Moratuwa.

ABEYGUNASEKARA, T., 1993, Study on Problemd Fased by Small Scale Contractors. Unpublished Dissertation (B.Sc). University of Moratuwa.

AKINCL, B. AND FISCHER, M., 1998. Factors affecting contractors' risk of cost overburden. Journal of Management in Engineering, January/ February, 6775.

ARBITI, D., 2000, Business Failures in Construction Industry. Engineering Construction and Architectural Management, 2000, Volume 7, Nr 2 Pg 120-132.

ARULINKA, M., 2001. A survey on problem faced by construction contractors in Sri Lankan construction industry. Unpublished dissertation (B.Sc) in Quantity Surveying. University of Moratuwa.

ASWORTH, A., 2004. Cost studies of buildings. 4th ed. London: Wesley Longman Ltd.

BALOI, D. AND PRICE, A.D.F. (2004). Evaluation of global risk factors affecting cost performance in Mozambique [online]. Loughborough University. Available from: http://www.rics.org/ Builtenvironment/Buildingcosts/ Risk_factors_cost_performance20041121.html [Accessed 23 May 2006].

BARBOSA, P.S.F. AND PIMENTEL, P.R., 2001. A liner programming model for cash flow management in the Brazilian construction industry. Construction management and Economics, 19,469-475.

BONNY, J.B. AND FREIN, J.P., 1973. Hand Book of Construction management and organization. New York: Nostrand Reinhold Company.

BOUSSABAINE, A.H. AND ELHAG, T., 1999. Applying fuzzy techniques to cash flow analysis. Construction management and Economics, 17,745755.

BOUSSABAINE, A.H., THOMAS, R. AND ELHAG, T.M.S., 1999.Modelling cost flow forecasting for water pipeline projects using neural networks. Engineering construction and architectural management, 6/3,213-224.

BOWER, D., 2000. A systematic approach to the evaluation of indirect costs of contract variations. Construction management and Economics, 18, 263268. 
CHAN, J., TAM, C. M. and CHEUNG, R., 2005. Monitoring financial health of Contractors at the aftermath of the Asian Economic Turmoil: A case study in Honk Kong, Construction Management and Economics, Volume 23, Nr 5, Pp 451-458.

CREEDY, G. (2005). Risk factors leading to cost overrun in highway projects [online].Brisbane, Queensland University of Technology. Available from: http://www.rics.org/Builtenvironment/ Buildingcosts Risk_factors_highway_projects2005 1121.html [Accessed 25 February 2006].

HARRIES, F. AND McCAFFE, R., 1995. Modern construction management. $4^{\text {th }}$ ed. Oxford: Blackwell Science.

HENDRICKSON, C. (1998). Project Management for construction [online]. Mellon University. Available from:http://www.ce.cmu.edu./pmbook/07/financing of constructed facilities.html [Accessed25 February 2006].

JACKSON, S., (2004). Project cost overruns and risk management [online]. University of Reading. Available from:http://www.rics.org/Builtenvironment/ cost_overruns_risk_management200411111.html [Accessed 15 May 2006].

KAKA, A.P. AND PRICE, A.D.F., 1993. Modeling standard cost commitment curves for contractors' cash flow forecasting. Engineering, management and Economics, 11, 271-283.

KAKA, A.P., 1996. Towards more flexible and accurate cash flow forecasting. Construction management and Economics, 14, 35-44.

KAKA, A. AND LEWIS, J., 2003. Development of a company-level dynamic cash flow forecasting model. Construction management and Economics, 21, 693705.

LAM, K.C., TIESONG, H.U., THOMAS, N.G., YUEN, S.M. AND WONG, C.T.C., 2001. Using an adoptive genetic algorithm to improve construction finance decisions. Engineering, Construction and Architectural Management, 8/1, 31-45.
LOWE, J. AND WHITWORTH, T. (1996). Risk management and contractor's cash flow [online]. Available from: http://www.rics.org/Management/ Businessmanagement / risk management 19960101.html [Accessed 19 May 2006].

MBACHU, J. I. C. AND NKADO, R. N. (2004). Reducing building construction costs: the views of consultants and contractors [online]. South Africa., University of Witwatersrand. Available from:http://www.rics.org [Accessed 01 June 2006].

MUSHTHAK, A.R.M., 2005. Impact of design changes on time and cost overruns in building projects. Unpublished dissertation (B.Sc) in Quantity Surveying. University of Moratuwa.

NAVON, R., 1995. Resource based model for automatic cash flow forecasting. Construction management and Economics, 13,501-510.

PALLIYAGURU, R. S., 2004. Is Mobilization Advance payment is necessary for Sri Lankan Construction Industry. Unpublished dissertation (B.Sc) in Quantity Surveying. University of Moratuwa.

REXI, C., 2004.simulation model for cost overruns in building projects. Unpublished dissertation (B.Sc) in Quantity Surveying. University of Moratuwa.

SUGANTHAN P. 2005. Simulation model for cost overruns of building elements. Unpublished dissertation (B.Sc) in Quantity Surveying. University of Moratuwa.

TREMEL, T.J. (2005). Financial management [online]. Available from: http://www.constructionrisk.com/ newsletter/articles/newsletter05-07.htm [Accessed 28 March 2006].

WIJEKOON, W.M.C.L.K., 2005. Factors affecting cash flow profile of contractors. Unpublished dissertation (B.Sc) in Quantity Surveying. University of Moratuwa.

WIJESOORIYA, R., 1997. How Banks can Assist Contractors to Manage their Cash Flows. Unpublished Dissertation (B.Sc). University of Moratuwa. 
Appendix

Table 1: Summery of Project Details

\begin{tabular}{|c|c|c|c|c|c|c|}
\hline $\begin{array}{c}\text { Project } \\
\text { Name }\end{array}$ & $\begin{array}{c}\text { ICTAD } \\
\text { Grade }\end{array}$ & $\begin{array}{c}\text { Type of } \\
\text { Building }\end{array}$ & $\begin{array}{c}\text { Contract } \\
\text { Sum (Rs.) }\end{array}$ & $\begin{array}{c}\text { Final } \\
\text { Account } \\
\text { Sum (Rs.) }\end{array}$ & $\begin{array}{c}\text { Total } \\
\text { Cost } \\
\text { Overruns }\end{array}$ \\
\hline P1 & M1 & $\mathrm{C}$ & $34,780,908.70$ & $43,434,487.36$ & $8,653,578.66$ & 24.88 \\
\hline ns (\%)
\end{tabular}

